\title{
Studi Perbandingan Jenis Sumber Air Terhadap Daya Tarik Nyamuk Aedes aegypti Untuk Bertelur
}

\author{
Mawardi $^{1^{*}}$, Rika Busra ${ }^{2}$ \\ ${ }^{\mathbf{1}}$ Balai Pelatihan Kesehatan Aceh - Banda Aceh \\ ${ }^{2}$ Fakultas Kesehatan Masyarakat Universitas Muhammadiyah Aceh - Banda Aceh \\ *Koresponden email: mawardi.ibrahim@gmail.com
}

Diterima: 29 Agustus 2019

Disetujui: 24 September 2019

\begin{abstract}
Dengue Hemorrhagic Fever (DHF) is an endemic disease caused by a virus and transmitted by vectors, especially Aedes aegypti and Ae. Albopictus. The number of cases tends to increase and is widespread in almost all regions. This study aims to determine the different types of water sources on the attractiveness of Aedes aegypti for laying eggs. The research method uses the One Way Anova statistical test analysis with $\alpha<0.05$. The results showed the One Way Anova test obtained $\mathrm{p}$ value $=0.048(\mathrm{p}<0.05)$ meaning that there are differences in the type of water source to the attractiveness of Aedes aegypti mosquitoes to lay eggs, especially in well water with river water with a value of $p=0.016(p<0,05)$. The difference in the number of mosquito eggs found in containers containing rain water, river water and well water indicates that the Aedes aegypti mosquito has different appeal in laying its eggs. The community should always maintain sanitation, especially containers that hold water so that it does not have the potential to become Aedes aegypti mosquito nest sites and can reduce the density of Aedes aegypti mosquitoes.
\end{abstract}

Kata Kunci: Aedes aegypti, Jenis Air, Demam Berdarah, Daya Tarik Nyamuk, Sanitasi

\begin{abstract}
Abstrak
Demam Berdarah Dengue (DBD) merupakan penyakit endemis disebabkan oleh virus dan ditularkan oleh vektor terutama Aedes aegypti dan Ae. albopictus. Jumlah kasus cenderung meningkat dan menyebar luas hampir semua wilayah. Penelitian ini bertujuan untuk mengetahui perbedaan jenis sumber air terhadap daya tarik Aedes aegypti untuk bertelur. Metode penelitian menggunakan analisa uji statistik One Way Anova dengan $\alpha<0,05$. Hasil penelitian menunjukkan uji One Way Anova diperoleh nilai $\mathrm{p}=0,048$ ( $\mathrm{p}<$ 0,05) artinya ada perbedaan jenis sumber air terhadap daya tarik nyamuk Aedes aegypti untuk bertelur terutama pada air sumur dengan air sungai dengan nilai $p=0,016(p<0,05)$. Adanya perbedaan jumlah telur nyamuk yang ditemukan pada wadah yang berisi air hujan, air sungai dan air sumur yang menunjukkan bahwa nyamuk Aedes aegypti memiliki daya tarik yang berbeda-beda dalam meletakkan telurnya. Masyarakat hendaknya selalu menjaga sanitasi terutama wadah-wadah menampung air sehingga tidak berpotensi menjadi tempat bertelur nyamuk Aedes aegypti dan bisa mengurangi kepadatan nyamuk Aedes aegypti.
\end{abstract}

Keywords : Aedes aegypti, Type of Water, Dengue Fever, Mosquito Attractiveness, Sanitation

\section{Pendahuluan}

Pembangunan kesehatan bertujuan untuk meningkatkan kesadaran, kemauan dan kemampuan hidup sehat bagi setiap orang agar terrwujud derajat kesehatan masyarakat yang setinggi-tingginya, sebagai investasi bagi pembangunan sumber daya manusia yang produktif secara sosial dan ekonomis (Undang-Undang Kesehatan, 2009; Notoadmodjo, 2003).

Demam berdarah adalah penyakit demam akut yang disebabkan oleh virus dengue, yang masuk ke peredaran darah manusia melalui gigitan nyamuk dari genus Aedes, misalnya Aedes aegypti atau Aedes albopictus. Aedes aegypti adalah vektor yang paling banyak ditemukan menyebabkan penyakit ini. Nyamuk dapat membawa virus dengue setelah menghisap darah orang yang telah terinfeksi virus tersebut (Kemenkes RI, 2013).

Aedes aegypti merupakan satu jenis nyamuk yang mudah berkembangbiak dan dapat hidup dekat dengan lingkungan manusia, kerena nyamuk ini dikenal sebagai nyamuk rumahan yang bertelur ditempattempat penampungan air bersih seperti tempat air minum, bak mandi yang ada didalam rumah atau juga kaleng- kaleng kosong yang berisi air hujan, lipatan-lipatan dan lekukan yang berisi air dan potongan 
bambu yang ada disekitar rumah. Selain itu, Aedes aegypti dapat menghisap darah hewan lain seperti mamalia, aves, reptilia dan amfibi untuk menghasilkan telur bagi nyamuk dewasa betina, sedangkan dewasa jantan di alam hanya menghisap cairan tumbuhan (Christoper, (1960) dalam Rahmawati (2004)).

Dari sekian banyak cara pemberantasan nyamuk yang dilakukan, pengendalian secara pengelolaan lingkungan/manipulasi lingkungan mempunyai dampak negatif yang sangat kecil terhadap lingkungan, manusia dan binatang. Pengendalian secara pengelolaan lingkungan contohnya adalah menjaga kebersihan lingkungan agar tidak memungkinkan bagi nyamuk untuk berkembangbiak. Untuk genangan air yang tidak dapat dihindari seperti tempat minuman burung, vas bunga dan perangkap semut dapat di isi dengan air yang kira-kira tidak disukai oleh nyamuk Aedes aegypti (Fitri, 2013; Damanik, 2002).

Menurut Focks (2003) dalam Ambarita (2008) ovitrap atau perangkap telur merupakan cara yang dapat dimanfaatkan dalam kegiatan pengamatan dan pengendalian vektor DBD. Menurut Dibo dkk (2005) dalam Ambarita (2008) ovitrap adalah perangkap telur yang berhubungan dengan perilaku meletakkan telur (oviposisi) nyamuk Aedes aegypti. Teknik ini merupakan aplikasi dari perilaku bertelur Aedes aegypti yang cenderung memiliki habitat perkembangbiakan artifisial dan tidak langsung berhubungan dengan tanah.

Pada tahun 2015 jumlah penderita DBD yang dilaporkan sebanyak 129.650 kasus dengan jumlah kematian sebanyak 1.071 orang (IR/Angka kesakitan $=50,75$ per 100.000 penduduk dan CFR/angka kematian $=0,83 \%$ ). Dibandingkan tahun 2014 dengan kasus sebanyak 100.347 serta IR 39,80 terjadi peningkatan kasus pada tahun 2015 (Kemenkes RI, 2013).

Berdasarkan permasalahan diatas, maka penulis tertarik untuk mengadakan penelitian mengenai "Perbedaan Jenis Sumber Air Terhadap Daya Tarik Nyamuk Aedes aegypti untuk Bertelur di Desa Lubok Batee Kecamatan Ingin Jaya Kabupaten Aceh Besar Tahun 2017”. Penelitian bertujuan mengetahui perbedaan jenis sumber air terhadap daya tarik nyamuk Aedes aegypti untuk bertelur menggunakan media ovitrap yang akan diisi dengan berbagai jenis sumber air, seperti air hujan, air sungai dan air sumur. Penggunaan berbagai media ovitrap ini untuk membuktikan seberapa banyak keberadaan telur nyamuk Aedes aegypti pada setiap jenis sumber air.

\section{Studi Literatur}

\subsection{Tinjauan tentang Nyamuk Aedes aegypti}

Marcellus (2007) dalam Hartomo (2008) menyebutkan bahwa nyamuk Aedes aegypti mempunyai peranan penting dalam bidang kesehatan yaitu sebagai vektor Demam Berdarah Dengue (DBD). Cara penularannya adalah setiap kali nyamuk menusukkan kanalnya (ujung moncongnya) ke kapiler darah manusia untuk menghisapnya, maka nyamuk segera mengekskresikan air liurnya yang mengandung anti koagulan (zat anti pembekuan darah) supaya darah mudah disedot yang juga mengandung virus dengue, sehingga air liur yang tercemar virus tadi menular ke manusia yang menjadi korban gigitannya.

Bila penderita digigit nyamuk penular, maka virus dalam darah ikut terhisap masuk ke dalam lambung nyamuk, selanjutnya virus akan memperbanyak diri dan tersebar diberbagai jaringan tubuh dan siap untuk ditularkan kepada or ang lain.

Christophers, (1960) cit. Lenhart et al (2005) dalam Ambarita (2008) menyatakan bahwa nyamuk Aedes aegypti adalah nyamuk yang sangat mampu beradaptasi dan berkembang biak pada kontainer (highly adapted container breeder). Nyamuk Aedes aegypti menyukai tempat-tempat penampungan yang berair jernih dan terlindung dari sinar matahari langsung sebagai tempat perkembangbiakan. Tempattempat perkembangbiakan seperti itu umumnya banyak dijumpai di dalam rumah dan sekitarnya. Selain itu juga nyamuk ini lebih menyukai habitat dengan sedikit bahan organik sebagai sumber makanan pada saat stadium larva.

Siklus hidup nyamuk Aedes aegypti dapat dilihat pada Gambar 1. Nyamuk Aedes aegypti mengalami metamorfosis sempurna (holometabola), dari telur, larva (jentik), pupa, hingga imago (dewasa). Selama bertelur, seekor nyamuk betina mampu meletakkan 100 butir telur. Biasanya, telurtelur tersebut diletakkan dibagian yang berdekatan dengan permukaan air, misalnya di bak yang airnya jernih dan tidak berhubungan langsung dengan tanah. Perkembangan dari telur sampai nyamuk $\pm 9-10$ hari (Kardinan, 2003) 


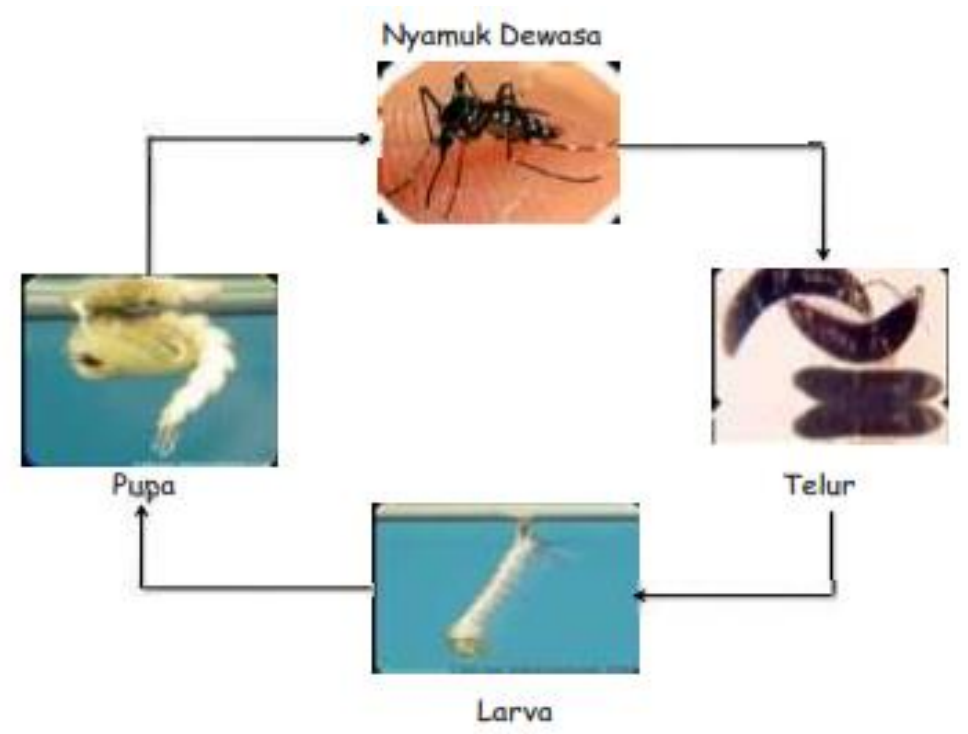

Gambar 1. Siklus hidup nyamuk

\subsection{Morfologi Nyamuk Aedes aegypti}

Aedes aegypti ini tersebar luas di seluruh provinsi di Indonesia, sering ditemukan di daerah pelabuhan yang ramai penduduknya, tapi dapat juga di daerah pedesaan yang diduga karena larva dari nyamuk ini terbawa melalui transportasi (Safar dan Rosdiana, 2009).

Spesies ini bermetamorfosis sempurna dengan melalui empat tahap, yaitu : telur, larva (jentik), pupa (kepompong) dan dewasa. Aedes aegypti mempunyai morfologi sebagai berikut :

\section{Telur}

Nyamuk betina meletakkan telurnya diatas permukaan air, menempel pada dinding perindukannya. Rata-rata setiap bertelur, nyamuk betina meletakkan 100 butir telur (Safar, 2009). Mortimer (1998) dalam Supartha (2008) menyebutkan karakteristik telur Aedes aegypti adalah berbentuk bulat pancung yang mula-mula berwarna putih kemudian berubah menjadi hitam.

Christophers (1960) dalam Kurniada (2001) menyebutkan bahwa telur Aedesaegypti diletakkan satu persatu pada dinding bejana yang berisi air, telur ini tidak mempunyai pelampung. Menurut Safar (2009), telur Aedes aegypti mempunyai pelana yang terbuka dan gigi sisir yang berduri lateral.

Christophers (1960) dalam Novelani (2007), menyatakan bahwa telur yang masih baru berwarna putih tetapi setelah satu atau dua jam berubah menjadi hitam berbentuk oval. Dinding luar telur (exochorion) mempunyai bahan yang lengket (glikoprotein) yang akan mengeras bila kering. Pada suhu antara $23^{\circ} \mathrm{C}-30^{\circ} \mathrm{C}$ dan kelembaban $60-80 \%$ telur akan menetas selama satu sampai tiga hari, sedangkan pada suhu $16^{\circ} \mathrm{C}$ memerlukan waktu menetas selama 7 hari setelah kontak dengan air, selanjutnya menjadi larva. Telur Aedes aegypti pada kondisi optimum dan dalam keadaan kering dapat bertahan selama enam bulan.

Soedomo (1971) dalam Novelani (2007) menyebutkan bahwa semakin lama telur yang disimpan dalam keadaan kering maka akan menunjukkan kemampuan daya tetas telur rendah. Telur yang disimpan selama 12 (dua belas) minggu atau tiga bulan, masih menunjukkan kemampuan untuk menetas walaupun sangat rendah. Kemampuan bertahan memberikan keuntungan bagi kelangsungan hidup spesies tersebut selama kondisi iklim yang tidak menguntungkan (WHO, 2004). Berdasarkan pengamatan dilaboratorium Institut Pertanian Bogor (IPB) oleh Agustina (2006) dalam Novelani (2007), telur yang disimpan selama dua minggu sudah mulai mengkerut dan kering.

\section{Larva}

Christophers (1960) dalam Novelani (2007) menyatakan bahwa larva Aedes aegypti berbentuk silindrik dengan kepala membulat, antena pendek dan halus, bernafas menggunakan pekten yang berada diruas ke delapan dari abdomen, sedangkan untuk mengambil makanan menggunakan rambut-rambut yang ada dikepala yang berbentuk seperti sikat. Tahap larva terdiri dari empat instar dan pergantian kulit terjadi empat kali, lama stadium larva ini enam sampai sembilan hari.

Menurut Putri (2008), ada empat tingkat (instar) jentik sesuai dengan pertumbuhan larva tersebut, yaitu : 

a. Instar I : berukuran paling kecil, yaitu $1-2 \mathrm{~mm}$.
b. Instar II : berukuran 2,5-3,8 mm.
c. Instar III : lebih besar sedikit dari larva instar II.
d.Instar IV : berukuran paling besar $5 \mathrm{~mm}$.

Christophers (1960) dalam Novelani (2007) menyatakan bahwa kondisi larva saat berkembang dapat mempengaruhi kondisi nyamuk dewasa yang dihasilkan. Untuk larva yang dipelihara, makanan yang dibutuhkan biasanya mengandung karbohidrat, protein dan asam amino. Berdasarkan hasil laporan, bila larva kekurangan protein dan asam amino ternyata tidak mencapai instar ke dua.

Menurut WHO (1982) dan Bates (1970) dalam Novelani (2007), selain makanan, larva juga dipengaruhi oleh suhu. Pada suhu air yang optimum $23-27^{\circ} \mathrm{C}$ dari instar ini menjadi dewasa hanya membutuhkan waktu kurang lebih dua minggu, larva Aedes aegypti dapat bertahan hidup pada suhu air dibawah $-2^{\circ} \mathrm{C}$ selama $2-10$ jam dan akan mati bila terpapar lebih dari 11 jam.

\section{Pupa}

Kettle (1984) dalam Kurniada (2001) meyebutkan bahwa bentuk pupa merupakan fase tanpa makan dan sangat sensitif terhadap pergerakkan air. Stadium ini hanya berlangsung 2-3 hari tetapi dapat diperpanjang sampai 10 hari pada suhu rendah, dibawah suhu $10^{\circ} \mathrm{C}$ tidak ada perkembangan. Kepompong (pupa) berbentuk seperti koma. Bentuknya lebih besar namun lebih ramping dibandingkan larva (jentik)nya. Pupa Aedes aegypti berukuran lebih kecil jika dibandingkan dengan rata-rata pupa nyamuk lain (Depkes RI, 2007).

Sungkar (2005) dalam Putri (2008) menyebutkan bahwa pupa terdiri atas sefalotoraks, abdomen, dan kaki pengayuh. Sefalotoraks mempunyai sepasang corong pernapasan berbentuk segitiga. Pada bagian distal abdomen ditemukan sepasang kaki pengayuh yang lurus dan runcing. Jika terganggu, pupa akan bergerak cepat untuk menyelam selama beberapa detik kemudian muncul kembali ke permukaan air.

Christophers (1960) dalam Novelani (2007) mangatakan bahwa pada tahap ini pupa tidak makan dan tergantung pada penyimpanan energi pada saat fase larva, suhu $23-27^{\circ} \mathrm{C}$, waktu yang diperlukan untuk menjadi nyamuk dewasa adalah selama 45 jam untuk jantan dan 60 jam untuk betina.

\section{Dewasa}

Womack (1993) dalam Novelani (2007) menyatakan bahwa nyamuk jantan selalu keluar lebih dahulu dari fase pupa walaupun pada akhirnya perbandingan jantan dan betina (1:1). Nyamuk jantan setelah berumur satu hari siap melakukan kopulasi dengan nyamuk betina. Nyamuk jantan umumnya mempunyai ukuran lebih kecil dari nyamuk betina dan pada antenanya terdapat rambut-rambut tebal yang berbentuk seperti sisir.

Nyamuk dewasa Aedes aegypti berukuran kecil, berwarna dasar hitam, dengan gelang-gelang (loreng) putih pada sepanjang toraks dan abdomen, dan bercak-bercak putih disayap dan kakinya. Menurut Sungkar (2005) dalam Putri (2008), bagian tubuh nyamuk dewasa terdiri atas kepala, toraks dan abdomen. Tanda khas Aedes aegypti berupa gambaran lyre pada bagian dorsal (mesonotum) yaitu sepasang garis putih yang sejajar ditengah dan garis lengkung putih yang lebih tebal pada tiap sisinya. Probosis berwarna hitam, skutelum bersisik lebar berwarna putih dan abdomen berpita putih pada bagian basal. Ruas tarsus kaki belakang berpita putih.

Christophers (1960) dalam Kurniada (2001) menyebutkan bahwa nyamuk betina bagian mulutnya (probosis) panjang disesuaikan untuk menusuk dan menghisap darah. Antenanya panjang (filiform) dan langsing terdiri dari 15 segmen. Antena nyamuk jantan memiliki banyak bulu (plumose), sedangkan pada nyamuk betina antenanya sedikit berbulu (pilose).

Suroso (2007) dan Nuruddin (2010) menyebutkan bahwa ciri-ciri nyamuk Aedes aegypti adalah sebagai berikut :

- Berwarna hitam dan belang-belang (loreng) putih pada seluruh tubuhnya.

- Berkembangbiak ditempat penampungan air dan barang-barang yang memungkinkan air tergenang.

- Tidak dapat berkembangbiak di selokan/got atau kolam yang airnya langsung berhubungan dengan tanah.

- Hidup didalam dan disekitar rumah, juga ditemukan ditempat umum.

- Mampu terbang sampai 100 meter. 
- Nyamuk betina aktif menggigit (menghisap) darah pada pagi hari sampai sore hari. Nyamuk jantan menghisap sari bunga/tumbuhan yang mengandung gula.

- Umur nyamuk Aedes aegypti rata-rata 2 minggu, tetapi sebagian diantaranya dapat hidup 2 - 3 bulan.

\subsection{Kebiasaan Hidup (Bionomik) Aedes aegypti}

Pengetahuan bionomik nyamuk meliputi stadium pradewasa (telur, jentik, pupa) dan stadium dewasa. Kebiasaan hidup/ bionomik dari nyamuk Aedes aegypti tersebut, terdiri dari:

\section{Kebiasaan Menggigit (Feeding Habit)}

Menurut Merrit dan Cummins (1978) dalam Supartha (2008), imago Aedes aegypti mempunyai perilaku makan yaitu menghisap nectar dan jus tanaman sebagai sumber energinya. Selain energi, imago betina juga membutuhkan pasokan protein untuk keperluan produksi (anautogenous) dan proses pematangan telurnya. Pasokan protein tersebut diperoleh dari cairan darah inang. Di dalam proses memenuhi kebutuhan protein untuk proses pematangan telurnya ditentukan oleh frekuensi kontak antar vektor dengan inang. Frekuensi kontak tersebut dapat dipengaruhi oleh jenis dan kepadatan inang.

Pada umumnya nyamuk Aedes menggigit pada pukul 9.00-10.00 WIB dan 16.00-17.00 WIB. Keadaan ini dapat berubah oleh pengaruh angin, suhu dan kelembaban udara dalam menambah atau mengurangi aktivitas di dalam menggigit (DEPKES, 2002).

\section{Kebiasaan/ perilaku Istirahat (Resting Habit)}

Nyamuk Aedes aegypti betina menghisap darah manusia setiap 2 hari. Protein dari darah tersebut diperlukan untuk pematangan telur yang dikandungnya. Setelah menghisap darah, nyamuk ini akan mencari tempat hinggap (beristirahat). Tempat hinggap yang disenangi adalah benda-benda yang tergantung seperti pakaian, kelambu atau tumbuhan didekat tempat perkembangbiaknya. Biasanya ditempat yang agak gelap dan lembab. Setelah masa istirahat selesai, nyamuk itu akan meletakkan telurnya pada dinding bak mandi/WC, tempayan, ban bekas, dan lain sebagainya. Biasanya sedikit diatas permukaan air. Selanjutnya nyamuk akan mencari mangsanya (menghisap darah) lagi dan seterusnya (Suroso, 2007).

\section{Kebiasaan Berkembangbiak (Breeding Habit)}

Tempat perkembangbiakan nyamuk Aedes aegypti adalah penampungan air bersih di dalam rumah ataupun berdekatan dengan rumah, dan air bersih tersebut tidak bersentuhan langsung dengan tanah. Tempat perkembangbiakan tersebut berupa:

a. Tempat penampungan air (TPA) yaitu tempat menampung air guna keperluan sehari-hari seperti drum, tempayan, bak mandi, bak WC dan ember.

b. Bukan tempat penampungan air (non TPA) yaitu tempat - tempat yang biasa digunakan untuk menampung air tetapi bukan untuk keperluan sehari-hari seperti tempat minum hewan piaraan, kaleng bekas, ban bekas, botol, pecahan gelas, vas bunga dan perangkap semut.

c. Tempat penampungan air alami (TPA alami/ natural) seperti lubang pohon, lubang batu, pelepah daun, tempurung kelapa, kulit kerang, pangkal pohon pisang dan potongan bambu. (Muhtholib dan Abdullah, 2001)

\section{Lama hidup}

Nyamuk Aedes aegypti dewasa memiliki rata-rata lama hidup hanya delapan hari. Selama musim hujan, saat masa bertahan hidup lebih panjang, hal ini menyebabkan risiko penyebaran virus semakin besar (Supartha, 2008).

\subsection{Perangkap Telur (Ovitrap)}

Ovitrap (singkatan dari oviposition trap) adalah perangkat untuk mendeteksi kehadiran Aedes aegypti dan Aedes albopictus pada keadaan densitas populasi yang rendah dan survey larva dalam skala luas tidak produktif (misalnya BI < 5), sebaik pada keadaan normal. Secara khusus, ovitrap digunakan untuk mendeteksi infestasi nyamuk ke area baru yang sebelumnya telah dieliminasi (Sayono, 2008)

Ovitrap standar berupa gelas kecil bermulut lebar dicat hitam bagian luarnya dan dilengkapi dengan bilah kayu atau bambu (pedel) yang dijepitkan vertikal pada dinding dalam. Gelas diisi air setengahnya hingga $3 / 4$ bagian dan ditempatkan di dalam dan di luar rumah yang diduga menjadi habitat nyamuk Aedes aegypti. Ovitrap memberikan hasil setiap minggu, namun temuan baru dapat memberikan hasil tiap 24 jam. Pedel diperiksa untuk menemukan dan menghitung jumlah telur yang terperangkap. Telur ditetaskan untuk menentukan spesies nyamuk Aedes aegypti (WHO, 2004). Ovitrap memiliki beberapa bagian, antara lain : media ovitrap, kasa penutup, ovistrip dan atraktan. 
Lama pemasangan ovitrap dilakukan selama lima hari dikarenakan waktu yang diperlukan untuk menyelesaikan perkembangan telur, mulai dari nyamuk menghisap darah sampai telur dikeluarkan, biasanya antara 3-4 hari. Jangka waktu tersebut disebut 1 siklus gonotropik (gonotropic cycle) (Depkes RI, 2010).

\section{Metode Penelitian}

Penelitian dilakukan di Desa Lubok Batee Kecamatan Ingin Jaya Kabupaten Aceh Besar pada tanggal 04 Desember 2017 sampai dengan 04 Januari 2018. Populasi sampel sebanyak 120 wadah dari air hujan, air sungai dan air sumur. Penelitian menggunakan variabel independen (variabel bebas) yang terdiri dari air hujan, air sungai dan air sumur. Sementara itu variabel dependen (variabel terikat) adalah jumlah telur nyamuk Aedes aegypti dari hasil pemasangan ovitrap. Kerangka konsep penelitian seperti pada Gambar 2. Adapun hipotesa penelitian sebagai berikut:

\section{Air Hujan}

Ha : Adanya perbedaan sumber air hujan terhadap jumlah telur nyamuk Aedes aegypti di Desa Lubok Batee Kecamatan Ingin Jaya Kabupaten Aceh Besar.

Ho : Tidak adan perbedaan sumber air hujan terhadap jumlah telur nyamuk Aedes aegypti di Air Sungai Desa Lubok Batee Kecamatan Ingin Jaya Kabupaten Aceh Besar.

Ha : Adanya perbedaan sumber air sungai terhadap jumlah telur nyamuk Aedes aegypti di Desa Lubok Batee Kecamatan Ingin Jaya Kabupaten Aceh Besar.

Ho : Tidak adan perbedaan sumber air sungai terhadap jumlah telur nyamuk Aedes aegypti di Desa Lubok Batee Kecamatan Ingin Jaya Kabupaten Aceh Besar.

\section{Air Sumur}

Ha : Adanya perbedaan sumber air sumur terhadap jumlah telur nyamuk Aedes aegypti di Desa Lubok Batee Kecamatan Ingin Jaya Kabupaten Aceh Besar.

Ho : Tidak adan perbedaan sumber air sumur terhadap jumlah telur nyamuk Aedes aegypti di Desa Lubok Batee Kecamatan Ingin Jaya Kabupaten Aceh Besar.

\section{Variabel Independent}

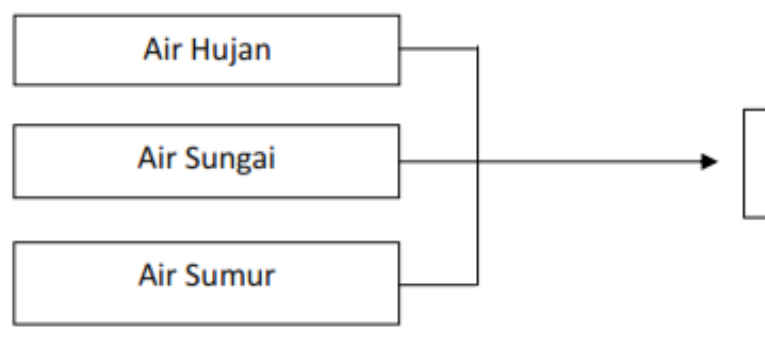

\section{Variabel Dependent}

Telur nyamuk Aedes aegypti

Gambar 2. Kerangka konsep penelitian

Analisa dianalisis dengan menggunakan uji anova satu arah, menggunakan komputer dengan aplikasi SPSS. Tahap penelitian sebagai berikut:

- Sampel air dimasukan ke dalam ovitrap hingga volume maksimal sekitar 3/4 bagian dari ovitrap. Pada permukaan air di bagian tepi gelas bagian dalam dilapisi dengan kertas HVS.

- Ovitrap dengan jenis air berbeda diletakkan di dalam kandang pemeliharaan nyamuk.

- Ovitrap didiamkan selama 3 (tiga) hari dan diperiksa pada hari ke-4 dengan menghitung banyaknya telur nyamuk yang terdapat dalam masing-masing ovitrap.

\section{Hasil dan Pembahasan}

Jumlah telur nyamuk Aedes aegypti yang ditemukan pada ovitrap dengan jenis air yang berbeda di Desa Lubok Batee Kecamatan Ingin Jaya Kabupaten Aceh Besar dapat dilihat pada Tabel 1. 
Tabel 1. Distribusi frekuensi jumlah telur nyamuk Aedes aegypti pada media air berbeda di Desa Lubok Batee Kecamatan Ingin Jaya

\begin{tabular}{|c|c|c|c|c|c|c|c|c|}
\hline \multirow{2}{*}{ No } & \multirow{2}{*}{ Sumber Air } & \multicolumn{4}{|c|}{$\begin{array}{c}\text { Jumlah Telur Nyamuk Aedes } \\
\text { berdasarkan Pengulangan }\end{array}$} & aegypti & & \multirow{2}{*}{$\begin{array}{l}\text { Rata- } \\
\text { Rata }\end{array}$} \\
\hline & & 1 & 2 & 3 & 4 & 5 & & \\
\hline 1 & Air Huian & 187 & 210 & 323 & 431 & 462 & 1.613 & 322,6 \\
\hline 2 & Air Sungai & 135 & 144 & 235 & 321 & 340 & 1.175 & 235 \\
\hline 3 & Air Sumur & 279 & 345 & 472 & 521 & 620 & 2.237 & 447.4 \\
\hline
\end{tabular}

Sumber : Data Primer (2018)

Berdasarkan Tabel 1 menunjukkan bahwa jumlah telur nyamuk Aedes aegypti yang paling banyak ditemukan pada ovitrap air sumur yang berjumlah 2.237 telur selama 5 kali pengulangan dengan rata-rata 447,4 telur. Sedangkan pada ovitrap air hujan jumlah telur nyamuk Aedes aegypti yang ditemukan berjumlah 1.613 telur selama 5 kali pengulangan dengan rata-rata 322,6 telur dan pada ovitrap air sungai jumlah telur nyamuk Aedes aegypti yang ditemukan berjumlah 1.175 telur selama 5 kali pengulangan dengan rata-rata 235 telur.

Hasil tersebut diatas menunjukkan perilaku daya tarik Ae. aegypti pada media air yang ada pada ovitrap. Ketertarikan nyamuk terhadap jenis air tertentu karena kandungan senyawa organik dan an organik yang mempengaruhi sehingga nyamuk dapat mendeteksi aroma melalui feremon aroma yang bersifat "chemical senses". Hal ini menunjukkan bahwa Ae. aegypti mampu beradaptasi dengan lingkungan yang ada khususnya lingkungan yang tidak menguntungkan.

Menurut Sayono dkk. (2016) melaporkan bahwa Ae. aegypti mampu bertahan hidup pada air got, air sumur gali dan PAM. Damanik (2002) melaporkan di tiga kelurahan bahwa telur Ae. aegypti lebih banyak ditemukan pada air sumur dan paling tidak disenangi adalah air PAM. Sementara Yahya dan Warni (2017) melaporkan bahwa nyamuk memiliki kemampuan untuk bertelur dan berkembang pada semua jenis air pada tempat perindukan baik air selokan dan air sumur gali. Ae. aegypti meletakkan telur (oviposisi) pada suatu media air dipengaruhi oleh beberapa faktor seperti indera penciuman, suhu, cahaya, kelembaban dan wadah penampungan air (Tilak dkk, 2005).

\subsection{Perbedaan Jenis Sumber Air Terhadap Daya Tarik Nyamuk Aedes aegypti}

Adapun hasil penelitian dan analisa statistik untuk melihat perbedaan jenis sumber air (air hujan, air sungai dan air sumur) terhadap daya tarik nyamuk Aedes aegypti untuk bertelur dapat dilihat pada Tabel 2.

Tabel 2. Hasil uji one way Anova pada rata-rata perbedaan jenis sumber air terhadap daya tarik nyamuk Aedes aegypti untuk bertelur

\begin{tabular}{|c|c|c|c|c|c|c|c|}
\hline \multirow[b]{2}{*}{ No } & \multirow[b]{2}{*}{ Jenis Air } & \multirow[b]{2}{*}{$\begin{array}{l}\text { Rata- } \\
\text { Rata }\end{array}$} & \multirow[b]{2}{*}{$\begin{array}{r}\text { Standart } \\
\text { Deviasi }\end{array}$} & \multirow{2}{*}{$\begin{array}{l}\text { Standar t } \\
\text { Error }\end{array}$} & \multicolumn{2}{|c|}{$95 \% \mathrm{CI}$} & \multirow[b]{2}{*}{$p$ Value } \\
\hline & & & & & $\begin{array}{l}\text { Lower } \\
\text { Bound }\end{array}$ & $\begin{array}{l}\text { Upper } \\
\text { Bound }\end{array}$ & \\
\hline 1 & Air Hujan & 322,60 & 124,749 & 55,789 & 167,70 & 477,50 & \multirow{4}{*}{0,048} \\
\hline 2 & Air Sungai & 235,00 & 95,789 & 42,838 & 116,06 & 353,94 & \\
\hline 3 & Air Sumur & 447,40 & 136,617 & 61,097 & 277,77 & 617,03 & \\
\hline & Total & 335.00 & 143,314 & 37,004 & 255,64 & 414,36 & \\
\hline
\end{tabular}

Sumber: Data Primer (2018)

Tabel 2. menunjukkan bahwa dari hasil uji anova diperoleh rata-rata jumlah telur Aedes aegypti yang terbanyak pada ovitrap air sumur yaitu 447,40 telur $(\mathrm{SD}=136,617, \mathrm{CI}=277,77-617,03)$, sedangkan yang paling sedikit pada ovitrap air sungai yaitu 235 telur $(\mathrm{SD}=95,789, \mathrm{CI}=116,06-$ $353,94)$. Hasil uji diperoleh nilai $\mathrm{p}=0,048$ ( $\mathrm{p}<0,05$ ) artinya ada perbedaan jenis sumber air (air hujan, air sungai dan air sumur) terhadap daya tarik nyamuk Aedes aegypti untuk bertelur.

Uji statistik (One Way Anova) diperoleh nilai $\mathrm{p}=0,048(\mathrm{p}<0,05)$ yang artinya ada perbedaan jenis sumber air (air hujan, air sungai dan air sumur) terhadap daya tarik nyamuk Aedes aegypti untuk bertelur 
dengan rata-rata jumlah telur Aedes aegypti yang terbanyak pada ovitrap air sumur yaitu 447,40 butir (SD $=136,617, \mathrm{CI}=277,77-617,03)$ dan yang paling sedikit pada ovitrap air sungai yaitu 235 butir $(\mathrm{SD}=$ 95,789, CI $=116,06$ - 353,94). Wurisastuti (2013) bahwa Ae. aegypti mau bertelur di berbagai air tercemar menunjukkan bahwa media air tercemar memiliki pengaruh yang nyata terhadap kesukaan bertekur Ae. aegypti pada $\mathrm{CI}=5 \%$ dengan nilai $\mathrm{p}$ - value sebesar $<0,0001$, bahwa air yang tercemar dengan kotoran sapi yang paling disukai oleh nyamuk untuk meletakkan telurnya.

\subsection{Uji Least Significant Difference (LSD) Perbedaan Jenis Sumber Air}

Uji Least Significant Different (LSD) digunakan untuk mengetahui perbedaan daya tarik nyamuk Aedes aegypti dalam meletakkan telur pada jenis air yang berbeda (air hujan, air sungai dan air sumur). Hasil perhitungan uji LSD dapat dilihat pada Tabel 3.

Berdasarkan uji LSD pada Tabel 3. diperoleh hasil bahwa tidak ada perbedaan yang signifikan antara ovitrap yang berisi air hujan dengan ovitrap yang berisi air sungai terhadap daya tarik nyamuk Aedes aegypti untuk bertelur dengan nilai $\mathrm{p}=0,272(\mathrm{p}=<0,05)$. Perbedaan daya tarik nyamuk Aedes aegypti untuk bertelur juga tidak didapat antara ovitrap air hujan dengan air sumur dengan nilai $\mathrm{p}=0,127$ $(\mathrm{p}=<0,05)$. Namun, ditemukan perbedaan yang signifikan antara ovitrap yang berisi air sungai dengan ovitrap yang berisi air sumur terhadap daya tarik nyamuk Aedes aegypti untuk bertelur dengan nilai $\mathrm{p}=$ $0,016(\mathrm{p}=<0,05)$.

Tabel 3. Hasil uji Least Significant Different (LSD) pada perbedaan jenis sumber air terhadap daya tarik nyamuk Aedes aegypti untuk bertelur

\begin{tabular}{|c|c|c|c|c|c|c|}
\hline \multirow[t]{2}{*}{ (I) Jenis Air } & \multirow[t]{2}{*}{ (J) Jenis Air } & \multirow{2}{*}{$\begin{array}{c}\text { Perbedaan Rata- } \\
\text { Rata (I-J) }\end{array}$} & \multirow[t]{2}{*}{ Std. Error } & \multirow[t]{2}{*}{ Sig. } & \multicolumn{2}{|c|}{ 95\% Confidence Interval } \\
\hline & & & & & Batas bawah & Batas Atas \\
\hline Air Hujan & $\begin{array}{c}\text { Air } \\
\text { Sungai } \\
\text { Air }\end{array}$ & 87,600 & 76,072 & 0,272 & $-78,15$ & 253,35 \\
\hline & Sumur & $-124,800$ & 76,072 & 0,127 & $-290,55$ & 40,95 \\
\hline Air & $\begin{array}{c}\text { Air Hujan } \\
\text { Air }\end{array}$ & $\begin{array}{l}-87,600 \\
-212,400 *\end{array}$ & 76,072 & 0,272 & $-253,35$ & 78,15 \\
\hline Sungai & Sumur & & 76,072 & 0,016 & $-378,15$ & $-46,65$ \\
\hline Air & Air Hujan & 124,800 & 76,072 & 0,127 & $-40,95$ & 290,55 \\
\hline Sumur & $\begin{array}{c}\text { Air } \\
\text { Sungai }\end{array}$ & $212,400^{*}$ & 76,072 & 0,016 & 46,65 & 378,15 \\
\hline
\end{tabular}

*. The mean difference is significant at the 0.05 level.

Sumber: Data Primer (2018)

Hasil uji LSD menunjukkan bahwa tidak ada perbedaan yang signifikan antara ovitrap air hujan dengan ovitrap air sungai terhadap daya tarik nyamuk Aedes aegypti untuk bertelur dengan nilai $\mathrm{p}=0,272(\mathrm{p}=<0,05)$. Perbedaan jumlah telur nyamuk Aedes aegypti juga tidak didapat antara ovitrap air hujan dengan ovitrap air sumur dengan nilai $\mathrm{p}=0,127(\mathrm{p}=<0,05)$. Namun, ditemukan perbedaan yang signifikan antara ovitrap yang berisi air sungai dengan ovitrap yang berisi air sumur terhadap daya tarik nyamuk Aedes aegypti untuk bertelur dengan nilai $\mathrm{p}=0,016(\mathrm{p}=<0,05)$.

Hasil penelitian ini sejalan dengan penelitian yang dilakukan oleh Damanik (2002) untuk mengetahui tempat perindukan yang paling disenangi nyamuk Aedes aegypti berdasarkan jenis sumber air, menunjukkan hasil bahwa ada perbedaan jenis sumber air terhadap jumlah larva Ae. Aegypti dalam 9 kali percobaan ulangan. Larva Aedes aegypti dalam pertumbuhannya membutuhkan zat-zat organik yang ada dalam air sebagai bahan makanannya ditambah dengan suhu yang mendukung yaitu antara $20^{\circ} \mathrm{C}$ $30^{\circ} \mathrm{C}$.

Nyamuk Aedes aegypti cenderung lebih menyukai/tertarik untuk meletakkan telur pada air sumur dibandingkan pada air hujan maupun air sungai. Hal tersebut dapat disebabkan karena kondisi air sumur gali yang digunakan pada penelitian ini terlihat jernih dan bersih, berbeda dengan air sungai yang keruh dan kuning. Penelitian yang dilakukan di Yogyakarta menunjukkan sumur terbukti sebagai habitat yang potensial untuk tempat perindukan nyamuk Ae. aegypti. Adanya kedalaman sumur hingga mencapai sekitar 15 meter tidak merupakan kendala bagi nyamuk Ae. aegypti betina untuk meletakkan telurnya di dalam sumur.

Karakteristik yang dimiliki air sumur, seperti rendahnya salinitas dan kandungan bahan organik, $\mathrm{pH}$ pada kisaran netral, tingkat kekeruhan yang rendah (jernih), dan juga volumenya yang besar sangat 
cocok untuk tempat hidup Ae. aegypti pradewasa, apalagi ditunjang dengan adanya kandungan mikroba dan organisme renik lain yang relatif tinggi sebagai sumber makanan utama bagi jentik. Karakteristik yang dimiliki air sumur tersebut menjadi daya tarik yang kuat bagi nyamuk betina untuk meletakkan telurnya di dalam sumur (Gionar, 2001).

Pada air hujan, jumlah telur nyamuk Aedes aegypti tidak memiliki perbedaan yang bermakna dengan jumlah telur pada air sumur. Hal ini dapat terjadi karena kondisi air hujan yang jernih dan bersih sehingga menjadi daya tarik bagi nyamuk Aedes aegypti untuk meletakkan telurnya.

Air hujan sebagai tempat perindukan yang disenangi nyamuk Ae. Aegypti setelah air sumur juga mengandung jasad renik yang dibutuhkan nyamuk sebagai bahan makanan. Air hujan merupakan jenis air yang paling murni, namun dalam perjalanannya ke bumi air hujan akan melarutkan partikel-partikel debu dan gas yang terdapat di udara sehingga air hujan yang sampai ke bumi sudah tidak murni dan reaksi kimia tersebut dapat mengakibatkan keasaman (Chandra, 2007).

Bila tidak menemukan tempat perindukan air bersih maka nyamuk Aedes aegypti beralih ke tempat lain yang sudah tercemar. Hal ini menjelaskan mengapa ditemukan telur nyamuk Aedes aegypti pada ovitrap yang terisi air sungai yang keruh dan kuning. Nyamuk Aedes aegypti mampu hidup tidak hanya pada air jernih tetapi juga dapat bertahan hidup dan tumbuh normal pada air kotor dan tercemar yang didiamkan menjadi jernih (Jacob dkk., 2014; Sayono, dkk., 2016).

\section{Kesimpulan dan Saran}

\subsection{Kesimpulan}

1. Jumlah telur nyamuk Aedes aegypti ditemukan pada wadah air hujan sebanyak 1.613 butir selama 5 kali pengulangan dengan rata-rata 322,6.

2. Jumlah telur nyamuk Aedes aegypti ditemukan pada wadah air sungai sebanyak 1.175 butir selama 5 kali pengulangan dengan rata-rata 235.

3. Jumlah telur nyamuk Aedes aegypti ditemukan pada wadah air sumur sebanyak 2.237 butir selama 5 kali pengulangan dengan rata-rata 447,4.

4. Ada perbedaan jenis sumber air terhadap daya tarik nyamuk Aedes aegypti untuk bertelur dengan nilai $\mathrm{p}=0,048(\mathrm{p}<0,05)$. Terutama pada air sumur dengan air sungai dengan nilai $\mathrm{p}=0,016(\mathrm{p}<0,05)$.

\subsection{Saran}

1. Bagi masyarakat diharapkan mengetahui keberadaan dan penyebaran larva Aedes aegypti, masyarakat dapat meningkatkan perhatian terhadap sanitasi tempat tinggal dan tempat breeding place nyamuk Aedes aegypti terutama pada wadah-wadah yang dapat menampung air disekitar tempat tinggal sehingga tidak berpotensi menjadi tempat bertelur nyamuk Aedes aegypti dan kepadatan nyamuk Aedes aegypti dapat berkurang.

2. Bagi institusi seperti Dinas Kesehatan dan Puskesmas melakukan Pemberantasan Sarang Nyamuk (PSN) Demam Berdarah Dengue baik di dalam maupun di luar rumah. Namun pelaksanaannya juga perlu difokuskan di lingkungan sekitar rumah (termasuk pekarangan, kebun, kandang hewan ternak, saluran limbah rumah tangga yang kemungkinan dapat dijadikan sebagai tempat berkembangbiaknya nyamuk Aedes aegypti) sehingga pada saat musim penghujan datang penyakit DBD tidak menjadi wabah.

3. Bagi peneliti selanjutnya perlu dilakukan pengkajian lebih lanjut tentang kandungan-kandungan kimia pada air yang menarik nyamuk Aedes aegypti dalam memilih tempat bertelur dan berkembang menjadi nyamuk dewasa.

\section{Daftar Pustaka}

Ambarita, Lasbudi, P. (2008). Peningkatan Daya Guna Ovitrap Untuk Pengamatan Nyamuk Aedes aegypti (Linn) Dengan Penggunaan Homogenat Stadium Akuatik Dan Air Bekas Kolonisasi, Yogyakarta, Program Pascasarjana Universitas Gadjah Mada Yogyakarta.

Chandra, Budiman, Pengantar Kesehatan Lingkungan, Jakarta : EGC, 2007.

Damanik, Dewi D, Tempat Perindukan yang paling disenangi Nyamuk Aedes aegypti berdasarkan Jenis Sumber Air : Skripsi, Fakultas Kesehatan Masyarakat, Universitas Sumatera Utara, 2002.

Departemen Kesehatan RI, Kajian Masalah Kesehatan Demam Berdarah Dengue, Jakarta : Badan Penelitian Pengembangan Kesehatan Departemen Kesehatan, 2003.

Fitri, Nanda, Rahma, Perbedaan Berbagai Jenis Media Tempat Perindukan yang Diberi Atraktan Terhadap Keberadaan Larva Nyamuk Aedes aegypti Tahun 2013 : Skripsi, Diploma IV Kesehatan Lingkungan, Politeknik Kesehatan Kemenkes Aceh, 2013. 
Gionar, R, Yoyo., Saptoro Rusmiarto., Dwiko Susapto., Iqbal R.F. Elyazar dan Michael J. Bangs, Sumur sebagai Habitat yang Penting untuk Perkembangbiakkan Nyamuk Aedes aegypti L : Jurnal Buletin $\begin{array}{lllll}\text { Penelitian } & \text { Kesehatan } & \text { Vol } & 29 & (1),\end{array}$ http://ejournal.litbang.depkes.go.id/index.php/BPK/article/download/2085/1200 (09 September 2019)

Hartomo, Pengaruh Berbagai Jenis Bahan Media Untuk Bertelur (Ovistrip) Terhadap Jumlah Telur Aedes aegypti Yang Terperangkap di Lingkungan Rumah : Skripsi, Fakultas Kesehatan Masyarakat, Universitas Muhammadiyah Semarang, (2008). Diakses tanggal 20 Mei 2014

Kardinan, Agus, Tanaman Pengusir dan Pembasmi Nyamuk, Jakarta: Agromedia, 2003.

Kementerian Kesehatan RI, Profil Kesehatan Indonesia 2012, Jakarta, 2013. http://www.kemkes.go.id. Diakses tanggal 23 Maret 2014. Kodoatie, Robert J; Sjarief, Roestam, Pengelolaan Sumber Daya Air Terpadu, Yogyakarta: ANDI, 2008.

Kurniada, Nina. (2001). Pengaruh Seleksi malation Terhadap Jangka Hidup Nyamuk Dewasa, Jumlah Kelompok Telur dan Jumlah Telur Nyamuk Aedes aegypti, Bogor: Institut Pertanian Bogor.

Muhtholib, Abdullah. (2001). Pedoman Surveilans Vektor, Jakarta: Ditjen PPM dan PL.

Novelani, Bonita, Ayu. (2007). Studi Habitat dan Perilaku Menggigit Nyamuk Aedes serta Kaitannya dengan Kasus Demam Berdarah di Kelurahan Utan Kayu Utara Jakarta Timur, Bogor: Institut Pertanian Bogor.

Notoadmodjo, Ilmu Kesehatan Masyarakat Prinsip-Prinsip Dasar, Jakarta: Rineka Cipta, 2003.

Nuruddin, Deni dan Mila, T. S. (2010), Buletin Sinergis, Batam: BTKL PPM Kelas I.

Putri, Maheka, Karmanie. (2008). Analisa Spasial Penyakit Demam Berdarah di Kota Madya Jakarta Timur. Skripsi: Fakultas Kesehatan Masyarakat, Universitas Indonesia.

Rahmawati, Dian, Jumlah dan Daya Tetas Telur, Serta Perkembangan Pradewasa Aedes aegypti di Laboratorium, Fakultas Kedokteran Hewan IPB, 2004.

Safar, Rosdiana. (2009). Parasitologi Kedokteran Protozoologi, Helmintologi, Entomologi, Bandung: Yrama Widya.

Sayono. (2008). Pengaruh Modifikasi Ovitrap Terhadap Jumlah Nyamuk Aedes Yang Terperangkap, Semarang.

Sayono, S, Qoniatun dan Mifbahuddin, Pertumbuhan Larva Ae. Aegypti pada Air Tercemar, Jurnal Kesehatan Masyarakat Indonesia 2016; 7 (1) : 15-21.

Supartha, I, Wayan. (2008). Pengendalian Terpadu Vektor virus Demam Berdarah Dengue, Aedes aegypti (Linn) dan Aedes albopictus (Skuse) (Diptera : Culicidae), Denpasar: Universitas Udayana.

Suroso, Thomas, Juru Pemantau Jentik, Pemberantasan Sarang Nyamuk Demam Berdarah Dengue, Jakarta: Departemen Kesehatan, 2007.

Yahya dan Sulfa Esi Warni, Daya Tetas dan Perkembangan Larva Aedes aegypti Menjadi Nyamuk Dewasa pada Tiga Jenis Air Sumur Gali dan Aie Selokan, Jurnal Vektor Penyakit, 2017. http://ejournal.litbang.depkes.go.id/index.php/vektorp/article/view/6036/4987 (09 September 2019).

Undang-Undang Republik Indonesia No. 36 Tahun 2009 tentang Kesehatan.

http://www.depkes.go.id/downloads/UU_No._36_Th_2009_ttg_Kesehatan.pdf

WHO, Pencegahan dan Pengendalian Dengue dan Demam Berdarah Dengue. Jakarta: EGC, 2004. 